\title{
The Sea Star Invertebrate Primitive Antibody (IPA):Rosetting And PFC (Plaque-Forming Cell). Anti- SRBC Antibodies
}

\author{
Michel Leclerc
}

\begin{abstract}
Next to the sea star T and B lymphocytes, we find the IPA (Invertebrate Primitive Antibody). Rosetting test and PFC test after Injection of SRBC (Sheep red blood cells)were performed in the sea starAsterias rubens (Echinodermata). Positive results were obtained and summarized in this work. They indicated the presence of anti-SRBC antibodies in the sea star, according to the method of Cunningham.
\end{abstract}

Index Terms - Invertebrate; sea star antibody; anti-SRBC.

\section{INTRODUCTION}

Rosetting test and PFC test (Plaque-forming cell) were clearly shown in the past. Cunningham [1] demonstrated the existence of Vertebrate antibodies by the use of the PFC method in 1965. 50 years later we recall a work which was obtained in sea star Asterias rubens after immunizations to SRBC (Sheep red blood cells) in vivo.

\section{MATERIALS AND METHODS}

\section{A. Rosetting Test}

Asterias rubens was injected with 5.000.000 SRBC treated with formol (to avoid osmotic lysis) : It corresponds to 0.05 $\mathrm{ml}$ of SRBC. 5 days after the injection, axial organ, a primitive lymphoïd organ [2], was removed and dilacerated ( by teasing) in physiologic serum. Fresh SRBC were added to obtain $2 \mathrm{ml}$ of cell suspension which was kept overnight at $4^{\circ}$ C. Observations were made in light microscopy. Controls without injection were performed. Specificity was tested with Pigeon red blood cells.

\section{B. PFC test}

We used Cunningham test [1]. 2 injections (1 per week) were realized in 10 Asterias rubens with the same quantity of SRBC as for Rosetting test. 5 days after the last injection. Axial organs were pooled and teased to obtain $1 \mathrm{ml}$ of cell suspension. Fresh SRBC in presence or not of Guinea pig complement were added to obtain $2 \mathrm{ml}$ of cell suspension. Controls without injection of SRBC were performed. Observations were done in light microscopy

\section{Results}

1) Rosetting appear in treated animals (injected with SRBC) but not in controls (Figure 1-A). We appreciate 5-6
Rosetting/ml. There are no Rosetting with PRBC (Pigeon red blood cells).

2) PFC also appear in treated animals but not in controls ( Figure 1- B-C ) It is noticeable that these PFC need no Guinea pig complement to be shown (sea star complement is already present [3].

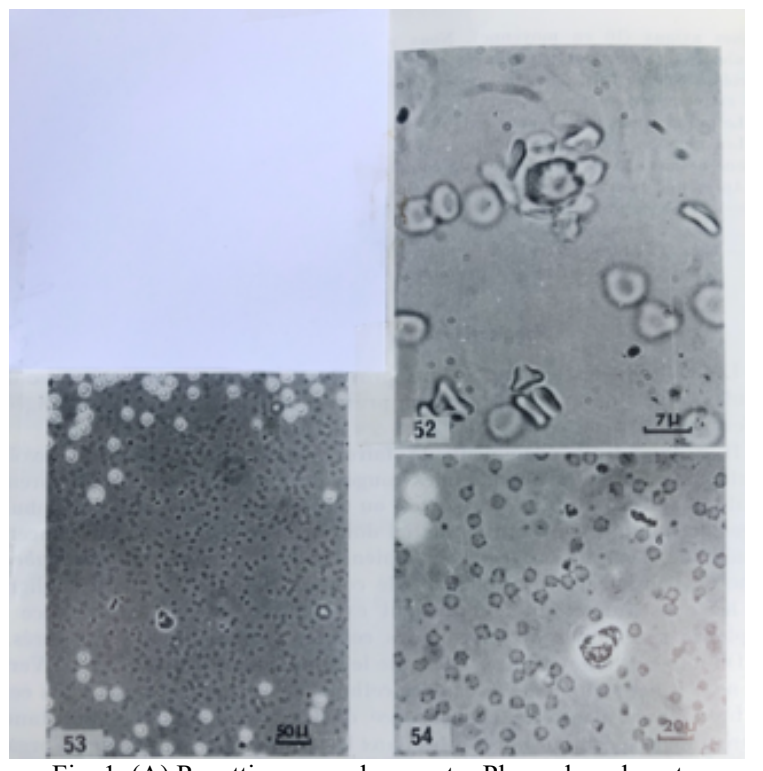

Fig. 1. (A) Rosetting around a sea star Plasmolymphocyte (B and C )PFC.Note in 54 the sea star Plasmolymphocyte at higher scale with ghost SRBC

\section{CONCLUSION AND DISCUSSION}

It appears clearly that anti-SRBC antibodies exist in sea star immune system. It is noticeable this humoral response is specific when SRBC test is compared to PRBC one (Pigeon red blood cells) : At the opposite of SRBC, PRBC don't agglutinate in presence of sea star plasmolymphocytes. Furthermore, these antibodies may be compared to specific hemagglutinins in the case of "Rosetting", to specific hemolysins in the case of PFC.

In this last one it must be declared that the presence or not of Guinea-pig complement is not necessary to realize PFC since we discovered the sea star complement in sea star genome (from $\mathrm{C} 1$ to $\mathrm{C} 9$ complement components) [3]. Further studies are necessary to compare anti-SRBC antibodies and IPA (Invertebrate primitive antibody) [4].

In conclusion, these results are of special interest in Comparative Immunology which concerns Invertebrates and Vertebrates. 


\section{REFERENCES}

[1] Cunningham, A.J (1965) Nature 207 : 1106-1107.

[2] Leclerc, M(1974) Thesis Doctorat ès Sc. Orléans France.

[3] Leclerc, $M$ et al (2013) Imlet 02-003.

[4] Leclerc, M (2013) ajisp 94-95. 